\title{
"I Don't Have the Nerve to Tell These People That I Cannot Help Them!": Vulnerability, Ethnography, and Good Intentions
}

\author{
Joana Catela \\ Instituto de Ciências Sociais, Universidade de Lisboa, 1600-189 Lisboa, Portugal; mjcatela@gmail.com
}

Received: 14 November 2019; Accepted: 7 December 2019; Published: 9 December 2019

check for updates

\begin{abstract}
The nonprofit organization where this ethnography took place, driven by the maxim "lending a hand", was forced to reduce its efforts to what it considered essential, at a time when austerity was beginning to take shape in Portugal. The analysis of the logics employed to distribute food to the neediest proved to be critical to the understanding of the consequences of apparent beneficial actions in this context. The concept of "vulnerable" is, therefore, discussed considering how it was produced by a legal instrument and how it was reproduced by a local institution, what were the consequences for the subjects involved in this research and also for the vulnerable ethnographer. This investigation was based on several months of intense fieldwork where different ethnographic methodologies were employed in order to grasp the complexities of vulnerability and good intentions, such as participants' observations and semi-directive interviews. Although this paper focuses on the analysis of the distribution of food support during a later visit to the fieldwork site, it is not the purpose of this paper to discuss issues of food shortage, but to contribute to the debate of care in the context of deprivation and precariousness, anchored in an ethnography where these concepts intertwine with real situations.
\end{abstract}

Keywords: medical anthropology; social housing; vulnerability; social suffering; good intentions; austerity

\section{Introduction}

Six months after finishing my doctoral research, I went back to the Health and Development Promotors (HDP) $)^{1}$. This nonprofit organization, founded in 2000, was celebrating its eleventh anniversary. Following a pilot project initiated at the now defunct Quinta do Mocho in Loures, one of the largest informally built neighbourhoods that had grown clandestinely between the 1970s and the 1990s mostly due to the arrival of immigrants from the former Portuguese colonies in Africa, cultural mediators were hired among the residents of this neighbourhood to act upon and improve the health of the local population. When the official implementation period of this project ended, these same promotors saw the need to continue the work. The desire to provide ongoing, rather than timely and exceptional services that addressed what they considered to be the most pressing issues motivated the official creation of an institution that later established itself in the new neighbourhood where residents were also relocated.

For eleven months, I undertook an intensive ethnography with this nonprofit organization that I returned to sometime after the fieldwork period was completed. Following Martins and Mendes,

1 The institution referred to in this article is protected by anonymity, as are all actors, who are therefore identified by pseudonyms. Formal consent of all participants was obtained during fieldwork and before each of the interviews. The methodology employed was approved by the Anthropology Department of ISCTE-IUL. 
when discussing the conditions under which ethnographers conduct fieldwork, "we return in order to understand time and again, always with the renewed hope of knowing something new, of being taught something new"2 [1] (p. 35), I decided to return for a day to the neighbourhood of Terraços da Ponte. This late visit is narrated in this article along with historical considerations about how vulnerability was produced in this territory and the ethnographic quandaries that emerge when researching populations considered vulnerable.

\section{The Production and Reproduction of Vulnerability in the Margins of Lisbon}

At the beginning of the 1990s, over 150,000 residents lived in shacks in the metropolitan areas of Porto and Lisbon. Portugal had joined the European Union in 1986 and international events were being planned for the capital city, such as Lisbon European Capital of Culture in 1994 and the 1998 World Exposition. At the same time, structural urban renewal projects were projected to redesign the metropolitan landscape. Following external and internal pressures, the government, consequently, decided to launch the Special Rehousing Program (PER, or Programa Especial de Realojamento, in Portuguese) to eradicate all shacks, rehouse the slum-dwellers in municipal houses, and upgrade the country's image.

Published on 7 May 1993 with a Decree-Law [2], and implemented during the subsequent two decades, the PER was launched by the XII Constitutional Government of Portugal. When it was enacted, the program was already an outdated housing program due to its inability to provide a thorough strategy of urban and regional development [3,4] and the sanitary discourse adopted regarding the rehoused population [5].

In order to operationalize the program, the government provided some of the necessary funds and ordered each municipality to complete a census and categorize the slum residents. The survey, employed during the summer of 1993, worked as a population technology [6], intended to classify and make the undistinguishable mass of occupants visible for bureaucratic purposes. It also defined and mapped formal and informal areas of the city for intervention purposes.

These rigid bureaucratic procedures and the top-down mechanisms of implementation, as well as the lack of social support during rehousing, transformed the PER, a mere financial instrument, into a social program with serious, albeit variable, territorial, social and political implications. Implementation depended on the efforts employed by each municipality and different results were achieved [7], which in some cases led to a replication of a culture of poverty $[5,8]$ based on a broad definition of vulnerable populations living in shanties that justified political and social intervention [9]. The decree overlooked household needs and focused on a specific typology that demanded elimination, i.e., the "barracas" or shacks, despite the existence of a multitude of informal architectural expressions and social arrangements in the different neighbourhoods.

The program focused on the construction of new infrastructures rather than urban regeneration and mainly aimed to construct housing projects in peripheral urban areas marked by poor infrastructure. When the municipalities did not disperse the original slums, these communities were physically and socially isolated in the ghettos. One of these neighbourhoods was Quinta do Mocho in Loures, located in the periphery of Lisbon.

The Quinta do Mocho's restructuring project involved the demolition of the informal houses and the construction of Urbanização Terraços da Ponte, a rent-controlled neighbourhood where the former 4000 residents had been transferred by the municipal council in 2001. After almost three decades, the abandoned residential project in Quinta do Mocho, occupied and creatively refurbished by the newcomers, was demolished. These residents, who had inhabited the four abandoned towers and for years invested in their "homes", were rehoused by the municipality of Loures in Terraços da Ponte. Because the material conditions surrounding them were assumed to be conducive to crime 
and underdevelopment, the top-down analysis of their lifestyle was conducted by applying housing policies regardless of local specificities or prior consultation with the population. At the same time, ad hoc initiatives that were designed to deal with urgent problems were adopted and implemented, such as organizing a group of cultural mediators chosen among the residents to tackle urgent health problems of the population. The evolution of this group into a nonprofit organization concerned with empowering a vulnerable population is considered in the next section of this paper.

\section{3. "What Is That Word They Like Us to Use? Oh Yes, Empowerment!" 3}

The official objective of eradicating slums in the metropolitan areas of Lisbon and Porto has been defined by its legislation as "a still-open scourge in our social fabric" [2], therefore simplified social exclusion through access to decent housing based on the stigmatization of life and sociocultural conditions of the residents living in the informal neighbourhoods [5]. These sites were characterized by their "advanced marginality" [9]. The neighbourhoods where clandestine construction proliferated described as perishing territories in need of intervention and socio-political reintegration policies. Vernacular and informal architecture was equated with a lack of moral and social adjustment. The unofficial and concealed goal of PER became the adjustment of the slum residents to a normalized and recognized lifestyle [5] and the inhabitants of Quinta do Mocho were rehoused in Terraços da Ponte under these assumptions.

As some anthropologists have noted, the margins of the state [10-12] function as natural peripheries or containers for individuals considered not sufficiently socialized within the law. The technologies adopted by programs targeting [13] populations deemed "vulnerable" living in these socially and spatially marginalized territories, ended up producing consequences similar to the ones these programs were ideally combating. The existence of power is, thus, paradoxically based on the need to constantly produce this marginal condition where many individuals find themselves [14], making them simultaneously victims and perpetrators [15-17]. These dynamics wind up perpetuating the binomial compassion and repression, which is engulfed in good intentions and is materialized by programs developed by state and non-state entities established locally when dealing with "vulnerable communities".

The increasing pathologization of behaviors based on precarious housing conditions and the belief that changing them would also discipline the lives of those targeted by these same programs, has led to a proliferation of local initiatives and institutions which direct and indirectly exert control over citizens' bodies and behaviors [18,19]. These projects frequently focus on health as the ideal governing technology, which has been "used as a shorthand for the capacity of the modern self to be transformed through the deployment of various rational practices of self" [16] (p. 45). This type of action [20], which decontextualizes the historical, political, and social production of suffering and vulnerability [21], is often well intended, but provokes unplanned consequences [22]. As Sliwinski stated when discussing the contradictions of international donations after an earthquake in El Salvador, "explaining vulnerability warrants considering the development history of a country. At the very least, it needs to take into account the accumulated effects of economics, political, and social factors that influence people's livelihoods and their environments" [23] (p. 20).

At the same time as these initiatives erupted, in places such as Quinta do Mocho, the subliminal goal of the PER Law Decree of acting upon the political subjectivity of residents following neoliberal demands [24], motivated each resident to incorporate and embody "policies, discourses, and practices that would 'free' an individual to govern (oneself)" [25] (p. 52). Unrestrained from their previous housing conditions, these individuals were meant to inhabit the new municipal houses and to upgrade

3 Taken from my field notes, this quote refers to an episode I observed and registered at HDP headquarters. Dona Angelina, the non-profit's president, whilst filling out a form to apply for funding for a psychosocial support project the institution intended to implement in the neighbourhood, was trying to find the right words in order to ensure its financing. 
their political and social subjectivity in order to feel empowered by their new living conditions [26]. For those unable to fulfil this goal, the nonprofit organizations, funded by private and public funders, acted like the neoliberal arms of the state [27] and took the responsibility for uplifting the population they served via projects and psychosocial programs.

In such cases, the use of a specific language appears as an essential condition in the relationship between organizations that depend on external funding and can be a determining factor in obtaining the capital needed for projects. During the course of my fieldwork, I had the opportunity to see the embarrassment of waiting for a new tranche from the private or state funders of HDP, which would allow them to pay salaries or top up the diesel tank of the nonprofit organization's van used to transport patients to the hospital or to meetings with official authorities. Throughout my eleven months of fieldwork, and due to my involvement as a volunteer ethnographer [28], I was constantly asked to assist the nonprofit managers who were applying for funding, but I was also involved in different activities and tasks for the organization which they could not afford to hire more help. Thus, the adoption of Anglo-Saxon terms and neologisms could distinguish successful financing from the total loss of funds for the following year, which would also imply firing or not hiring qualified workers, and thus deliver poorer service.

For Cruikshank [26], however, the democratic values of citizenship and self-regulation have been presented as the ideal solution for poverty, crime, and other social problems, acting as a government strategy aiming at transforming individuals into liberal citizens. The good intentions deployed in programs responsible for helping people to help themselves and which, in turn, unfold into citizenship technologies (speeches, programs, etc.), ensure that subjects are politically active and rationally self-governing. The author states, inspired by Foucault [29] and Rose [24], that citizens are not born politically inclined and motivated to work on themselves; they are "made" according to the power relations that simultaneously enable and constrain their subjectivity. However, these depend on the subjects' voluntary compliance, which does not mean that they are not coercive and do not interfere in various social dimensions. Subject citizens are free, but their freedom is a condition for power to operate over them.

Cruikshank also analyzes how the concept of empowerment reached relevance in the second half of the twentieth century, both for individuals and institutions. This universal appeal that brought together the interests of feminists, civil rights activists, environmentalists, among many others, has become a citizenship technology, that is, "a method for turning individuals into citizens and maximizing their political participation" (p. 67). The upsurge and dissemination of the buzz word "empowerment' was market inspired and promised not only self-governing but the autonomy of individuals. In order to act on the interests and desires of others to drive their actions to an appropriate end, power works through, and not against, the subjectivities of individuals and demands the subject's ability to adjust themselves to new social realities $[25,30]$. Maximizing the capacities of the powerless makes the poor self-reliant, active, productive, and participatory, i. e., citizens, which makes the use of concepts such as "empowerment and self-esteem almost mandatory in goal statements when nongovernmental organizations apply for funding" [26] (p. 94).

For the author, this movement is based on a war on the poor, who are isolated and targeted by state intervention. Their capacities are circumscribed, calculated, and engraved in policies that aim to remove them from a predefined situation and to justify specific intervention upon them. Social reformers emerge and their actors multiply on the ground. This modeling of the poor, which is based on their own involvement and investment, is based on the production of a leveling and standardizing class, duly known, adequately formulated in statistics, and supported by psychosocial disciplines [24]. The characteristics of the various groups that make up the new category of the poor share a culture of poverty, lack of power, civic participation, and motivation to solve their own problems. This ideology was established with the desire to empower those who are deprived of these qualities, based upon the assumption of the common good. 
In the field, institutions, such as HDP, implement and develop these ideas on the population they are trying to serve. The real intentions of governing and regulating bodies has made psychologists, social workers, and even the leaders of organizations on the ground feel that they know what is best for the communities they serve, even more than themselves. Furthermore, the dependence of external financiers, make these institutions closer to the mentality of the donors, of which they are usually unaware of, than that of the vulnerable communities, acting as state replacements or liaisons on a local level [31,32], unexpectedly popular in neoliberal or austerity contexts. This compassion that moves them to lend a hand [33], to label their clients as "vulnerable", and to use the jargon that makes them worthy competitors in the funding race, corresponds to a practice of doing good that is hardly criticized [15].

HDP was fueled by the need to reduce the suffering of needy, vulnerable, and marginalized individuals, as these subjects had been characterized by a Law Decree, in 1993, which motivated the creation of one of its pioneering projects, "Lending a Hand" in 2006. This project was oriented towards personal and social upgrading, as well as to the promotion of recreational activities to combat the isolation and social exclusion of some of Terraços da Ponte inhabitants who were previously living in Quinta do Mocho, but also individuals who had come to Portugal from the former African colonies with scarce means to undergo medical treatment and lived in the neighbourhood. The focus was gradually shifted to illegal immigrants, to other residents, and to similar neighbourhoods that were considered to be in need of support as well. "Lending a Hand" has received and was dependent on the financial support from different public and private entities and its continuation demanded a thorough compliance with bureaucratic procedures.

However, what was the result when the empowerment of these communities and individuals was yet to be completed when funds ran out? The next chapters explore how a nonprofit organization in an informal and rehousing neighbourhood tackled the vulnerability of the population it served after a national financial crisis shattered the country's already declining welfare system. But first, we need to consider the role of the ethnographer when investigating" vulnerable communities".

\section{Materials and Methods: Becoming Vulnerable in the Field}

Contrary to what was said of anthropology for years, the objective of ethnography is not to confront what is said with what is done, but rather to integrate discursive formulations [34]. Anthropology drives us to find similarities rather than differences. It is not a search for the "other", more sensitive or more vulnerable, but rather a quest for the commonality between two distant worlds, whether in different hemispheres or at the end of a main road uniting different experiences of people living in a European capital, as I came to find out during my PhD fieldwork.

Given the impossibility of being able to grasp exactly "what those who hear us understand about what we say, because their referential worlds will always be different from ours" [35] (pp. 113-114), the recognition of similarity makes it possible to apply a principle of coherence based on shared facts, or mutuality. In the incessant search for the perception of what "being human" means, anthropologists seek to understand the differences by following paths common to both the researcher and the interlocutor, however distant their reference worlds may be.

Anthropological knowledge can only be produced through a condition of mutuality. It is this condition that allows us to situate ourselves in relation to the context of observation. Mutuality is always constitutive of the place where the anthropologist positions himself. In the sense that mutuality implies "being with", "being in the company of", this condition is therefore co-constitutive of the other, neither anterior nor external [36] (p. 592).

According to Mapril and Matos Viegas [34], due to the very conditions of reciprocity that are established in the field and that require a constant negotiation and adjustment of the methods, the construction of the research object is not linear. The need to explain the hypotheses and exact methodologies to explore it, which is a common practice in other scientific disciplines, is not easily 
replicated in an ethnographic setting and somehow makes the physical presence and pertinence of the researcher more vulnerable, frail, and in need of constant negotiation.

However, if anthropologists assume that the process of knowledge construction is based on a constant transformation that takes place in the networks of social relations that make up the ethnographic terrains, this intersubjectivity that develops on the basis of shared revelations allows for the constant formulation of the categories themselves. By intersubjectivity, however, Mapril and Matos Viegas did not understand a way of knowing what others retain trapped inside their minds or participating in their activities without becoming them, a general assumption in traditional monographies [37], but to conceive the conditions of knowledge production linked to the social relations that produce them. The intersubjective experience inherent in ethnographic research makes it not a means to an end, but a way of producing knowledge itself and to "arrive at a range of humbler concepts through the labour of ethnographic description" [38] (p. 339). This dimension of ethnography allows for the adjustment and the redefinition of posture and methods in the field and in the face of unexpected situations." In other words, it is the ethnographer's imperfection and inadequacy that reveal the differences, as well as their constant effort of correction and approximation" [39]. This type of permeability and contamination, that exposes both interlocutor and investigator to vulnerability [40], are both integral and fertile to ethnography, and therefore need to be taken into consideration in the knowledge production process [39].

As Berg [41] realized while conducting a multi-situated research in Spain and Cuba on political memories among expatriated Cubans, contrary to what classical ethnographies point to as the norm, her fieldwork immersion was not gradual until it reached enviable levels of proximity to the interlocutors. Berg travelled a much more winding path, approaching and distancing herself from her object and interlocutors on several occasions, constantly negotiating her role within the relations established with Cubans in various diasporic contexts. Her effort constituted a successive investment in the construction of her research ground so that it would not escape her, a burden most ethnographers carry with them while conducting research and, particularly, when investigating sensitive or vulnerable subjects and topics.

During the course of my research I have repeatedly felt the same obstacles. The difficulties in delimiting the terrain, along with numerous impediments, were partly overcome by a physical proximity to the institution and a continuous and a laborious participant observation exercise. Sometimes the nonprofit organization that sheltered me was the root of the obstacles in my fieldwork, because I was inevitably confused as one of the trainees when volunteering for the institution, a mandatory condition to guarantee access to patients and the daily life of the institution. Detaching myself from this label was sometimes complicated and counterproductive to my own research. There were interlocutors that I approached more closely, and others with whom I had to negotiate proximity at different times. I frequently felt that defining my position was a strenuous and continuous task, and each conversation, each observation, motivated new ways of sharing, new understandings, and new research perspectives. Albeit demanding, being there and reflecting upon the fieldnotes these negotiations produced [42], resulted in a better understanding of the paradoxical work of both the institution and the trainees, with whom I was frequently mistaken for.

Similar to Berg, I also began my research following a snowball technique, which mimicked the social relations in this context [43]. I first asked the NGO president about the type of support given and the residents who were under their care who were classified as mentally ill. I proceeded with interviews and informal conversations with these individuals, the NGO, and the municipal workers operating in the field. The already sullen theme of mental health, often associated with issues of these immigrants without legal documents, dependent on subsidies, and social support, complicated the already labyrinthine issues surrounding any ethnographic endeavour, and forced me to a continuous task of field making, justifying Mapril's [44] assertion, that "the field is never chosen, but produced" (p. 56). 
As a result of this mutual aid agreement between the nonprofit organization and myself, as both a volunteer and an ethnographer, I conducted several research exercises, such as observations of the interactions between the psychologist and the social worker interns and the community they were trying to help. I accompanied residents to doctors' appointments and to interviews with social workers monitoring their cases. I was present in several meetings with state and non-state entities, such as the Portuguese Immigration and Borders Service, the municipal immigration department, and the International Organization for Migration with whom the NGO had active protocols. I also helped with small tasks, such as visiting a resident suffering from depression or helping to fill in an application for a job, just to list a few. These activities were all part of the endless list of tasks the interns were supposed to perform daily. I helped them as much as I could and observed how they conducted their relationships with the residents.

As Davies stated [45], this kind of reflexivity is particularly relevant in social sciences, but mostly in ethnography where intersubjectivity, mutuality, and empathy become integral to the comprehension of the context in which knowledge is produced. Although emotionally demanding [28], the ethnographer's availability to find a shared and common ground during fieldwork adopted during visceral, sensorial, and sensitive ethnographic immersion permits to capture the plasticity of subjectivities and the incongruences of lived experience, in order to better understand and construct experience-laden concepts such as vulnerability [38] in its multidimensional interpretations, involving interlocutors and ethnographers in the field.

We are therefore not talking about "becoming like the other" or projecting or attributing our emotional state to others, but learning or understanding the unknown through analogy or resonance with our experiences, in constant tension between ourselves and the other in a dialogical process through which the anthropologist and his interlocutor reveal, illuminate and transform their personal identities in an attempt to create a common referential universe [39] (p. 48).

I also realized that participation in the association's dynamics simultaneously fostered approach and withdrawal experiences that also conditioned my selection of research methods. Sometimes, if participant observation was welcomed, as when there was no one available to drive a resident to an appointment at the hospital, I took this as an opportunity to ask the patient some questions relevant to my research. If it was necessary for someone to accompany one of the nonprofit managers to a meeting, it provided another opportunity to attend and participate. As well, in other cases, I chose to observe and annotate the daily interactions inside the nonprofit organization between users and interns. On other occasions I was invited to attend meetings with official authorities, where relevant discussions were being held and the presence of an HDP representative was mandatory.

The continuous presence in the field provided me with a broader and more constant display of the conversations, verbal and nonverbal communications, incongruities and contradictions, continuities and ruptures, to record daily life and the ordinary in my fieldwork notebook [42], but also to strategically select the next step of analysis and methodology to employ. Participant observation allowed me to be there, to live the reality of HDP for several months, and to consolidate my knowledge. The semi-directive script [46] with the key questions to address, which allowed my interlocutors to feel free to give relevance to topics that would be important to them and that would compel me to reassess the guidelines of my research, was reviewed several times, but also set aside whenever the discourse of my interlocutors was more relevant than my incipient concerns.

There were several and constant negotiations regarding my role at the nonprofit organization with the users who resourced its aid when caught in several political, domestic, and health entanglements, and the interns who made that territory their daily workplace. Added to these were the demands placed upon myself by virtue of my willingness to volunteer which demanded an almost total availability on my part to support the organization constantly struggling with financial and technical problems, a dual and ambiguous role where anthropologists researching NGOs constantly find themselves $[27,47]$. 


\section{Results and Discussion: Homecoming}

In December 2011, when I returned to Terraços da Ponte, Portugal was under a new bailout, similar to what had happened in 1977 and 1983. Five years in power, the socialist government was facing international pressures driven by alarming socioeconomic indicators, a sovereign debt crisis, an excessive deficit, and a rampant unemployment rate. This led to a formal request for financial assistance. The third bailout finally came to Portugal through the hands of three entities, the European Commission, the European Central Bank, and the International Monetary Fund, which was implemented by the XIX Constitutional Government elected on the 21 June 2011, composed of a new coalition between center right parties. The critical financial situation and the measures taken to overcome it paved the way for substantial changes to the welfare state [48], which were accompanied by a reconceptualization of the support provided to those who deserved to benefit from social support [49].

On the day I revisited the nonprofit organization, it seemed like it had entered a pre-apocalyptic state, as if the news from the newspapers that warned us every day of further austerity measures had suddenly materialized in front of me. Although the institution was never a place of great abundance, where two trainees struggled daily to solve as they could, and without great means, the various problems that entered through the door, the escalating scarcity of recent months had not prepared me for the scenario I encountered. Upon arrival, there was only Mariana, the psychologist, in sight, who was busy managing and distributing goods from the Food Bank. The day ahead was anticipated to be particularly hectic with the organization of bags to be delivered and the arrival of the users, who were waiting for their turn, after confirming that they were registered and that they would be entitled to food aid.

The association's entrance was now divided into two zones separated by screens. The space, formerly centered on psychosocial support, had been reorganized into what seemed to me to be currently HDP's main activity: distribution of food to the needy. On the left side, duly protected from outsiders' eyes, were shelves of various food items from the Food Bank with which the HDP now had an active protocol. Cereal boxes, pasta, rice, sausages, tuna, and olive oil could be found scattered around the place or already displayed on the newly installed shelves. The interior of the fridge, where our lunches were previously stored, was filled with yogurt pots and other perishable items. The freezer bulged with sliced bread, sausages, butter, and cheese. In addition to these goods, crates filled with bananas, tomatoes, pears, turnips, bread, and spinach could be found everywhere. There were also vanilla desserts, cookies, saltine crackers, and milk packets waiting to be properly packaged in bags assigned to the homes of all who had duly justified their need for food support.

Mariana kept some assets for certain families whose needs were already known because they had young children, for health reasons or even considering their already proclaimed preferences. In the case of a mother who had to leave her children early in the nursery in order to get to work on time, Mariana was careful to prepare two large bags reinforced with fresh products for the children's soup, fruit, yogurt, and their preferred breakfast cereals. To ensure that she received the long-awaited goods, Mariana arrived at the nonprofit organization about an hour early, solely for this mother, who only at the end of her long working day could lift up the second bag. In addition to arriving early, Mariana also left later due to the demanding schedule of this woman, who once attended the job search workshop held at the nonprofit organization and was now working full time. She represented the epitome of the caring mother, the fulfilling client, the citizen whose example was referred to others [26]. Therefore, she deserved special treatment, even at the expense of Mariana's sleep.

They also told me that since Senhor Ramiro, the association's president, had suffered a car accident, destroying the van previously used to collect Food Bank goods and take patients to doctor appointments, several changes had taken place. First, both the psychologist and the social worker interns were fired. Although their internship had terminated in June, the institution was able to keep them working full time, but with the accident they were forced to let them go due to lack of funds. Now they supported the distribution of food only on a voluntary basis and moved by compassion for the poor, who they once helped on a different basis, namely, with psychological and social support [50-52]. 
When the partnership was established with the Food Bank, the registrations collected indiscriminately by Dona Angelina practically with all the residents of the neighbourhood were cancelled and the process underwent a more rigorous scrutiny in accordance with the rules imposed by the giving institution, deferring several applications which did not fulfil the specified criteria. I asked Mariana what they were looking for during the home visits ordered by the Food Bank and she told me that they saw the conditions in which people lived, what foods they had, if they were name-branded or generic, although this was a dubious standard since the applicant could still have food items from previous visits to the Food Bank. Although the research methods were not perfect, they were nevertheless applied by the former interns to guarantee the support's fittingness.

Mariana, while organizing the deliveries, took the opportunity to explain to me how she managed the operation as required by the Food Bank. They found that some people owed two euros for transportation, an amount charged by HDP to each family to fund the nonprofit's workers visit to the Food Bank warehouse after the van accident. The psychologist affirmed that taking that step had been enough to distinguish those who "really needed" from those who abused this service, because of the ridiculous and symbolic value asked in order to receive a "free" bag of food. In Mariana's words, the situation was solved using a simple calculation: "They decided that they would donate monthly to transportation. They said that their contribution was barely enough to buy a bottle of olive oil at the supermarket and that if they backed the transportation, they would have access to two bags of goods, so it was a more advantageous situation."

Although definite rules had been established about what each person was entitled to receive, not only to comply with the requirements of the Food Bank's protocol, the interns, according to what they already knew from each family, followed a more "subjective" or "intuitive" approach in choosing what was deposited in each bag. I noticed on this visit that Mariana (I later checked with Carla, the social worker, when she arrived) had already gained a greater complicity with the residents of the neighbourhood since my last visit. She knew them by name, she had already visited their homes, she was acquainted with their needs and preferences. She had listened to them listing their burdens and sorrows and she had become one of the guardians of the neighbourhood Food Bank refrigerator and pantry. I also noticed that she had some "pampering' reserved for certain people, as was the case of a woman who returned late in the afternoon asking, in a low voice, if Mariana could give her some extra items in case there were some remaining, to which Mariana replied to, in the same tone, that "Yes, maybe it could be arranged". The interns had, thus, become receptors of the narratives of suffering presented by the users and responded with compassion, actively participating in the moral economies at stake [15].

These compassionate efforts employed by the former interns, which involved staying until very late on Food Bank days and taking on the heavy work of loading and unloading, without any help, the van rented only for this purpose, was coincident with the logic of "lending a hand" [33] prevalent when they worked officially for the nonprofit organization. The compassion, the moral imperative that was above any other narrative was now the only one that subsisted when everything else at HDP seemed to crumble in the face of financial collapse. However, this abandonment was all the more necessary during austerity times. Touched by the community's needs and suffering, they had become infected by the communicable vulnerability [30] present in their complaints, moving them to act, to do something, to lend a hand. They did so in the name of a common humanity, which they justified as a universal imperative [53] and impelled them to work even without pay, in the name of the welfare of others and to alleviate their suffering [50,52]. This narrative, which established a hierarchy of priorities in which the hunger of the users of the association for which they used to work outweighed their personal needs, became dominant.

Provided the community deficiencies were properly marked and the vulnerability of this neighbourhood was once again defined by formal instruments such as the Food Bank inquiries and mandatory home visits, the goods were delivered and on the scheduled day the residents lined up at the nonprofit's door to collect their two bags full of "free food". They also did so as long as people 
complied with their part of the agreement, i.e., that the refrigerators in their homes remained devoid of essential food, that they were visible on the poverty lists, and that they managed to pay the two euros. Stronger compassionate forces would, if necessary, be activated by a mother struggling to get to her job on time. These same forces allowed for a "little treat" to be kept for others, but they also stratified and hierarchized who "really deserved" and who was not sufficiently compliant to receive support, which was made available to the detriment of the life of the former workers. It did not solve the problem in its genesis and did not allow for any kind of counterargument because, as is well known, compassion knows no enemies [15,16]. Similar to what Bornstein [54] found in her ethnography with Christian ONGs in Africa, the attitude of Mariana and Carla allows us to understand how an economy of care and ethics operates, and under which moral imperatives the possibilities for help are determined [55].

However, in practical terms, HDP struggled to reward all this effort. One of the managers, Dona Angelina, confided to me that, unfortunately, it did not seem that the readmission of the former interns would happen any time soon, because "nobody gives us money" and "there are cuts everywhere". By the end of 2011, the austerity discourse was widespread and structural cuts to the welfare state and its subsidiaries were deemed indispensable [48,49].

However, this dedication and self-sacrifice deployed by the former trainees to the residents of Terraços da Ponte was not overlooked by its inhabitants. One member of the HDP board regretted the departure of the interns and told them that in the neighbourhood everyone called them their "mulatto mothers". The effort had been rewarded, because of their atonement, shared vulnerability, and recognition of the helpless conditions lived by the residents of the neighbourhood, both Mariana and Carla were now considered honorary members of Terraços da Ponte.

When, at the end of the day, Senhor Ramiro and Dona Angelina arrived at HDP, Mariana confronted them with the arrival of many individuals requesting Food Bank assistance and the impossibility of HDP helping them all. She asked if she had to refuse the new applications submitted during the day. "I don't have the nerve to tell these people that I cannot help them!", she confided to me later. Senhor Ramiro accepted the newly arrived inscriptions but added that these would be the last.

When Dona Angelina arrived, she also shared with me that Adelaide, a former resident who I had met during fieldwork, was finally working as a housemaid, but no longer lived in the neighbourhood. This information had already been transmitted to me by Mariana, namely that Adelaide had left her daughter with her father and moved in with her sister somewhere far from Terraços da Ponte, something that both the psychologist and the social worker disapproved of and viewed as child abandonment. Sometimes Adelaide would return to the nonprofit organization, always telling a different story. The cycle continued and renewed, while interns and institution assisted passively without being able to lend a compassionate hand to Adelaide.

\section{Conclusions}

This paper explains how the vulnerability of a community was produced by the enactment of a special rehousing program in the 1990s and reproduced by the local institutions operating in the field. The objective of this paper is to critically and ethnographically discuss how, in the face of strenuous financial constraints, the moral economy of compassion was reorganized by a nonprofit organization focussed on helping a population considered "vulnerable". It also presents the figure of the ethnographer, both vulnerable and viscerally engaged with the field, for whom fieldwork is more than a rite of passage, it is a mandatory condition for the production of anthropological knowledge.

Returning to HDP after several months of absence, allowed me to conclude that ensuring the physical survival of the residents, rather than addressing the socioeconomic reasons that caused them suffering, had become the norm. It was necessary to help, not to waste time questioning what instigated it. The urgent matters that had directed the constitution of a group of cultural meditators in the 1990s were again the main driving forces behind their work with the community.

In order to prevent fraud and encourage appropriate civic participation, the morally charged discourse disseminated by nonprofit organizations working with the poor distorts the economic 
responsibilities that generate poverty. This is equated with a behavioral deviation, pathologized and instituted as an object of expert intervention, in which helping those who were" made' as those who need it most, ultimately divert attention away from socioeconomic inequalities. They fail to recognize the historical and political conditions that promote suffering, as well as the actions they employ that ultimately increase it rather than decrease it [21]. By not addressing vulnerability correctly, they make even more complex the situations of the individuals to whom they try to" lend a hand". It legitimizes and perpetuates structural imbalances and permits the survival of individuals in extreme situations without these causes being addressed or discussed [47]. These forms of "governing for health" [16] (p. 48) lead to the creation of new forms of subjectivity in which the structures of institutions are absorbed by individuals, creating a sense of individual failure [56] and expanding the power of the state in original ways when, in neoliberal times, it seems to be retracting.

Institutional responses tend to fragment these problems into differentiated smaller pieces which then become the subject of highly particularised technical policies and program, increasingly ones that last for short periods of time and then are replaced by yet others which further rearrange and fracture these problems [57] (p. 29).

But what were the real motivations behind the work of HDP, only humanitarian? Where did the desire or even the need to help come from? Where to allocate needs and vulnerability, I wondered, only on the side of the recipient of aid? Considering the "contingencies and playful' creativity or aesthetic self-construction to represent individual lives, to which the image of the victim often seems inadequate, partial at most, and humiliating" [58] (p. 9), the concepts of agency and resistance punctured my ethnography, forcing me to rethink such broad concepts. The data collected prevented me from understanding individuals as mere victims, benefactors as the sole disinterested active agents, or the government of the former as the equivalent of a serial production of amorphous and passive subjects.

Similar to Malkki [59], who criticized Fassin and Rechtman's [60] stance on humanitarianism, which focused mostly on the lack of satisfaction of the other's basic needs as a key factor in the decision to help, the reality present in the nonprofit organization directed the interpretation of the ethnographic data to a realm where precariousness and vulnerability intertwined daily [38]. The pursuit of a more fulfilling life, more satisfying levels of sociability than those found in his or her homeland, or the need to belong to something that transcended them existentially, were some of the reasons Malkki found in the course of her research that pushed not only caring for others, but also caring for oneself among Red Cross volunteers [29].

HDP interns also expressed a desire to help the residents of the neighbourhood, particularly those with whom they most easily identified. Although they stated that they did so to address the precarious or fragile situation in which they found these individuals, there was also an active quest to fill gaps on their side, to help them make sense of their work and daily life at the nonprofit organization. Like the nuns helping after the earthquake, in 2001, that devasted El Salvador, the former interns interiorized their humanitarian work as a "gift of self" [23] (p. 69). Citizenship technologies [24,26] were being deployed on both side of the "help barricades".

These ambiguities and paradoxes registered during intensive periods of fieldwork in omnipresent ethnographic notebooks enable the thorough analysis of institutions and the hazy modalities of care managed during austerity times, which some authors have noted that in the Portuguese case were responsible for the survival of some deprived families at the expense of a comprehension of the scope of scarcity these same individuals had to endure [47].

Because "NGOs are not simply monoliths carrying out the latent agendas of their partners, but a 'bundle of contradictions', a site of 'dynamic cooperation and conflict among its partners' and, arguably, within themselves" [32] (p. 262), in order to make sense of the inherent contradictions present in their work and the type of care they deliver to the populations they serve, ethnography obliges us to discuss their" vulnerability". This vulnerability, which is also shared with the ethnographer and the workers involved in psychosocial aid, attests to the original ways in which it intertwines with the lives of individuals. The help deployed is not perfect, it does not exempt the state of its responsibilities and 
rests on "ways to care for one another in a context where their very relations, and the very struggle to maintain the everyday, are at stake. Of course, they often fail, and tragically so. But they keep trying to the very end" [56] (p. 203).

Funding: This research was funded by the Fundação para a Ciência e a Tecnologia, grant number SFRH/BD/37673/2007.

Conflicts of Interest: The author declares no conflict of interest.

\section{References}

1. Martins, H.; Mendes, P. Trabalho de campo antropológico: (con)vivendo e conhecendo com muitos outros. In Trabalho de Campo: Envolvimento e Experiências em Antropologia; Martins, H., Mendes, P., Eds.; Imprensa de Ciências Sociais: Lisboa, Portugal, 2016; pp. 17-38.

2. Portugal. Law-Decree 163 from May 7th. 1993. Available online: https://dre.pt/pesquisa/-/search/274242/ details/maximized (accessed on 8 December 2019).

3. Tulumello, S.; Ferreira, A.C.; Colombo, A.; Di Giovani, C.; Allegra, M. Comparative planning and housing studies beyond taxonomy: A genealogy of the special programme for rehousing (Portugal). Trans. Assoc. Eur. Sch. Plan 2018, 2, 32-46. [CrossRef]

4. Ferreira, A.; Guerra, I.; Freitas, M.J. (Eds.) As pessoas não são coisas que se ponham em gavetas. In Sociedade e Território; Edições Afrontamento: Porto, Portugal, 1994; Volume 20.

5. Cachado, R. O programa especial de realojamento. Ambiente histórico, político e social. Anal. Soc. 2013, 206, 134-152.

6. Ascensão, A. Slum gentrification in Lisbon, Portugal: Displacement and the imagined futures of an informal settlement. In Global Gentrifications: Uneven Development and Displacement; Lees, L., Shin, H.B., López-Morales, E., Eds.; Policy Press: Bristol, UK, 2015; pp. 37-58.

7. Dubois, V. Towards a critical policy ethnography: Lessons from fieldwork on welfare control in France. Crit. Policy Stud. 2009, 3, 221-239. [CrossRef]

8. Antunes, G. Da Musgueira à Alta de Lisboa. Recomposição social e Urbana; Chiado Editora: Lisboa, Portugal, 2015.

9. Wacquant, L. Urban Outcasts: A Comparative Sociology of Urban Poverty; Polity Press: Cambridge, UK, 2008.

10. Aretxaga, B. Maddening states. Annu. Rev. Anthropol. 2003, 32, 393-410. [CrossRef]

11. Agamben, G. O Poder Soberano e a Vida Nua—Homo Sacer; Editorial Presença: Lisbon, Portugal, 1998.

12. Das, V.; Poole, D. Anthropology in the Margins of the State; USA Press: Santa Fe, NM, USA, 2004.

13. Inda, J.X. Targeting Immigrants: Government, Technology, and Ethics; Blackwell Publishing: Malden, MA, USA, 2006.

14. Miagusko, E. A produção das margens do estado no centro de São Paulo: Sem-teto nas ruínas de um presídio abandonado. Etnográfica 2014, 18, 33-52. [CrossRef]

15. Fassin, F. Compassion and repression: The moral economy of immigration policies in France. Cult. Anthropol. 2005, 20, 362-387. [CrossRef]

16. Pussetti, C.; Barros, V. The care of the immigrant self: Technologies of citizenship and the healthcare sector. Int. J. Migr. Health Soc. Care 2012, 8, 42-50. [CrossRef]

17. Pussetti, C.; Barros, V. Outros corpos: Imigração, saúde e etnopolíticas da cidadania. Fórum Sociológico 2012, 22, 23-31. [CrossRef]

18. Adorno, R. A cidade como construção moderna: Um ensaio a respeito de sua relação com a saúde e as "qualidades de vida". Saúde Soc. 1999, 8, 17-30. [CrossRef]

19. Burchell, G.; Gordon, C.; Miller, P. (Eds.) The Foucault Effect: Studies in Governmentality; The University of Chicago Press: Chicago, IL, USA, 1991.

20. Kleinman, A.; Das, V.; Lock, M. (Eds.) Social Suffering; University of California Press: Berkeley, CA, USA, 1997.

21. Gardner, K. "Our own poor"': Transnational charity, development gifts, and the politics of suffering in Sylhet and the UK. Mod. Asian. Stud. 2018, 52, 163-185. [CrossRef]

22. Hanna, B.; Kleinman, A. Unpacking global health: Theory and critique. In Reimagining Global Health: An Introduction; Farmer, P., Kim, J.Y., Kleinman, A., Basilico, M., Eds.; University of California Press: Berkeley, CA, USA, 2013; pp. 15-32. 
23. Sliwinski, A. The Moral Economy of Post-Disaster Aid in El-Salvador; McGill-Queen's University Press: Montreal \& Kingston, QC, Canada, 2018.

24. Rose, N. Governing the Soul-The Shaping of the Private Self; Free Association Book: London, UK, 1999.

25. Fennell, C. "Project Heat" and Sensory Politics in Redeveloping Chicago Public Housing. Ethnography 2011, 12, 40-64. [CrossRef]

26. Cruikshank, B. The Will to Empower: Democratic Citizens and Other Subjects; Cornell University Press: Ithaca, NY, USA, 1999.

27. Meertz, E.; Timmer, A. Getting it done: Ethnographic perspectives on NGOs. PoLAR Polit. Leg. Anthropol. Rev. 2010, 33, 171-177. [CrossRef]

28. Augusto, F.R.; Hilário, A.P. “Through the looking glass": The emotional journey of the volunteer ethnographer when researching sensitive topics with vulnerable populations. Qual. Rep. 2019, 24, 17-30.

29. Foucault, M. História da Sexualidade III—O Cuidado de si; Relógio D’Água: Lisbon, Portugal, 1994.

30. Fennell, C. The Museum of Resilience: Raising a Sympathetic Public in Postwelfare Chicago. Cult. Anthropol. 2012, 27, 641-666. [CrossRef]

31. Rodrigues, C. O envolvimento dos moradores nos programas de realojamento no Portugal democrático. Configurações 2012, 9, 181-193. [CrossRef]

32. Keshavjee, S. Blind Spot: How Neoliberalism Infiltrated Global Health; University of California Press: Berkeley, CA, USA, 2014.

33. Catela, J. "Lending a hand": The well-intentioned work of a non-profit organisation on the outskirts of neoliberal Lisbon. Int. J. Hum. Rights Healthc. 2019. ahead-of-press. [CrossRef]

34. Mapril, J.; Matos Viegas, S. Mutualidade e conhecimento etnográfico. Etnográfica 2012, 16, 513-524. [CrossRef]

35. Pina Cabral, J. Semelhança e verossimilhança: Horizontes da narrativa etnográfica. Mana 2003, 9, $109-122$. [CrossRef]

36. Patriarca, M. Como nos tornamos antropólogos? Imprevisto e mutualidade na constituição do terreno etnográfico da saúde mental em Lisboa. Etnográfica 2012, 16, 589-618. [CrossRef]

37. Malinowski, B. Los Argonautas del Pacífico Occidental: Un Estudio Sobre Comercio y Aventura Entre los Indígenas de los Archipiélagos de la Nueva Guinea Melanésica; Edicions 62: Barcelona, Spain, 1975.

38. Han, C. Precarity, precariousness, and vulnerability. Annu. Rev. Anthropol. 2018, 47, 331-343. [CrossRef]

39. Pussetti, C. Quando o campo são emoções e sentidos. Apontamentos de etnografia sensorial. In Trabalho de Campo: Envolvimento e Experiências em Antropologia; Martins, H., Mendes, P., Eds.; Imprensa de Ciências Sociais: Lisboa, Portugal, 2016; pp. 39-56.

40. Behar, R. The Vulnerable Observer. Anthropology That Breaks Your Heart; Beacon Press: Boston, MA, USA, 1996.

41. Berg, M.L. O desafio de encontrar e definir "o terreno": Reflexões em torno de uma investigação entre a diáspora cubana em Madrid. In Terrenos Metropolitanos: Ensaios Sobre Produção Etnográfica; Pedroso de Lima, A., Sarró, R., Eds.; Imprensa de Ciências Sociais: Lisbon, Portugal, 2006; pp. 35-51.

42. Sanjek, R. (Ed.) Fieldnotes: The Makings of Anthropology; Cornell University Press: London, UK, 1990.

43. Vespeira de Almeida, S.; Ferreira, S. Dictatorships and revolutions in Portugal and Chile: Ethnography, memory and invisibilities. Hist. Anthropol. Chur. 2015, 26, 597-618. [CrossRef]

44. Mapril, J. Passageiros de Schengen: A dialética entre fluxo e encerramento no trabalho de campo. In Terrenos Metropolitanos: Ensaios Sobre Produção Etnográfica; Pedroso de Lima, A., Sarró, R., Eds.; Imprensa de Ciências Sociais: Lisbon, Portugal, 2006; pp. 53-71.

45. Davies, C.A. Reflexive Ethnography: A Guide to Researching Self and Others; Routledge: London, UK, 1999.

46. Beaud, S.; Weber, F. (Eds.) Guia Para a Pesquisa de Campo: Produzir e Analisar Dados Etnográficos; Vozes: Petrópolis, Brasil, 2007.

47. Schuller, M. Killing with Kindness: Haiti, International Aid, and NGOs; Rutgers University Press: London, UK, 2012.

48. Pedroso de Lima, A. O cuidado como elemento de sustentabilidade em situações de crise. Portugal entre o estado providência e as relações interpessoais. Cad. Pagu 2016, 46, 79-105. [CrossRef]

49. Pussetti, C. The fallopian dilemma: African bodies, citizenship and family planning. J. Racial Ethn. Health Disparities 2015, 2, 21-33. [CrossRef] [PubMed]

50. Muehlebach, A. On affective labour in post-Fordist Italy. Cult. Anthropol. 2011, 26, 59-82. [CrossRef]

51. Elisha, O. Moral ambitions of grace: The paradox of compassion and accountability in evangelical faith-based activism. Cult. Anthropol. 2008, 23, 154-189. [CrossRef] 
52. Prince, R.; Brown, H. (Eds.) Volunteer Economies: The Politics and Ethics of Voluntary Labour in Africa; James Currey Press: New York, NY, USA, 2016.

53. Feldman, I.; Ticktin, M. (Eds.) In the Name of Humanity: The Government of Threat and Care; Duke University Press: London, UK, 2010.

54. Bornstein, E. The Spirit of Development: Protestant NGOs, Morality, and Economics in Zimbabwe; Stanford University Press: Palo Alto, CA, USA, 2003.

55. Fassin, D. Les économies morales revisitées. In Annales. Histoire, Sciences Sociales; Cambridge University Press: Cambridge, UK, 2009; pp. 1237-1266. [CrossRef]

56. Garcia, A. The Pastoral Clinic: Addiction and Dispossession Along the Rio Grande; University of California Press: Berkeley, CA, USA, 2010.

57. Biehl, J.; Good, B.; Kleinman, A. Transformations in social experience and subjectivity. In Subjectivity: Ethnographic Investigations; Biehl, J., Good, B., Kleinman, A., Eds.; University of California Press: Berkeley, CA, USA, 2007.

58. DelVecchio Good, M.J.; Hyde, S.T.; Pinto, S.; Good, B. (Eds.) Postcolonial Disorders; University of California Press: Berkeley, CA, USA, 2008.

59. Malkki, L. The Need to Help: The Domestic Arts of International Humanitarianism, 1st ed.; Duke University Press: London, UK, 2015.

60. Fassin, D.; Rechtman, R. The Empire of Trauma: An Inquiry into the Condition of Victimhood; Princeton University Press: Princeton, NJ, USA, 2009.

(C) 2019 by the author. Licensee MDPI, Basel, Switzerland. This article is an open access article distributed under the terms and conditions of the Creative Commons Attribution (CC BY) license (http://creativecommons.org/licenses/by/4.0/). 